\title{
Effectiveness of Academic Detailing to Optimize Medication Prescribing Behaviour of Family Physicians
}

\author{
Harpreet Chhina ${ }^{1,2}$, Vidula M.Bhole ${ }^{1,3}$, Charles Goldsmith ${ }^{1,4}$, Wendy Hall ${ }^{5}$, Janusz Kaczorowski ${ }^{6}$, Diane Lacaille ${ }^{1,7}$ \\ ${ }^{1}$ Arthritis Research Centre of Canada Vancouver, BC, Canada; ${ }^{2}$ Department of Experimental Medicine, Faculty of \\ Medicine, University of British Columbia, Vancouver BC; ${ }^{3}$ Epi Solutions Consultancy Services, Thane, India; ${ }^{4}$ Faculty of \\ Health Science, Simon Fraser University, Burnaby, BC Canada; ${ }^{5}$ School of Nursing, University of British Columbia, \\ ${ }^{6}$ Department of Family and Emergency Medicine and CRCHUM, University of Montreal, ${ }^{7}$ Division of Rheumatology, \\ Faculty of Medicine, University of British Columbia, Vancouver BC.
}

Received, August 6, 2013; accepted, August 23, 2013; published, August 25, 2013.

\begin{abstract}
PURPOSE. To synthesize current knowledge about the effectiveness and the magnitude of the effect, of Academic Detailing (AD), as a stand-alone intervention, at modifying drug prescription behavior of Family Physicians (FPs) in primary care settings. METHODS. A search of MEDLINE, EMBASE, CENTRAL, and Web of Science databases of all English language articles between January 1983 and July 2010 was conducted. We hand-searched the bibliographies of articles retrieved from the electronic search to identify additional studies. Inclusion criteria were: full-length articles describing original research; randomized controlled trial (RCT), or observational study design with a control group; studies of AD delivered to FPs; AD as a stand-alone intervention; drug prescription as the target behavior. Data extraction was done independently by two reviewers. Outcomes evaluated were: the difference in relative change in prescription rate between the intervention and control groups; the difference in absolute change in prescription rate between the intervention and control groups; and effect size, calculated as the standardized mean difference. RESULTS. 11 RCTs and 4 observational studies were included. Five RCTS described results showing effectiveness, while 2 RCTs reported a positive effect on some of the target drugs. Two observational studies found AD to be effective, while 2 did not. The median difference in relative change among the studies reviewed was $21 \%$ (interquartile range $43.75 \%$ ) for RCTs, and 9\% (interquartile range $8.5 \%$ ) for observational studies. The median effect size among the studies reviewed was - 0.09 (interquartile range 2.73). CONCLUSION. This systematic review demonstrates that AD can be effective at optimizing prescription of medications by FPs. Although variable, the magnitude of the effect is moderate in the majority of studies. This systematic review also provides evidence supportive of the use of $\mathrm{AD}$ as a strategy to promote evidence based prescription of medications or incorporation of clinical guidelines into clinical practice.
\end{abstract}

This article is open to POST-PUBLICATION REVIEW. Registered readers (see "For Readers") may comment by clicking on ABSTRACT on the issue's contents page.

\section{INTRODUCTION}

Gaps between research, policy and practice have been identified globally, with attention focused on making research-based evidence easily available so that it can facilitate change in the behaviours of health practitioners. Clinicians and family physicians (FPs) in particular, are faced with burgeoning scientific literature on a variety of topics, making it difficult to stay up to date. Current evidence suggests that dissemination of research results through peer-reviewed publications alone and conventional continuing medical education (CME) techniques have little effect $[1,2]$ while interactive techniques, such as audit/feedback, academic detailing and reminders, have been shown to be effective for changing physician behaviour or healthcare outcomes[3].

Academic detailing (AD), or educational outreach visits, is a form of CME in which a trained health care professional, such as a physician or pharmacist, visits physicians in their offices to provide evidence-based information on a selected topic [4-6]. Some of the important elements of AD are: a) identifying and defining the problem and specific behaviours to be promoted or discouraged;

Corresponding Author: Harpreet Chhina, Arthritis Research Centre of Canada, 5591 No. 3 Rd, Vancouver, BC, Canada; Email: chhina.harpreet@gmail.com 
b) examining baseline knowledge and motivations for current practice patterns; c) defining clear objectives for behaviour change; d) establishing credibility of the information provided by referencing unbiased information sources; e) providing interactive and short sessions with opportunity for discussion; f) highlighting and reinforcing key messages with concise graphic information; and g) providing positive reinforcement through follow-up visits [4].

Despite originating in 1983 [7], adoption of $\mathrm{AD}$ by health policy planners as a health service intervention is fairly new. In Canada, AD was first systematically introduced in Nova Scotia in 2001 [5] and is now implemented in six provinces $[8,9]$. Although the effectiveness of AD to influence the knowledge and practice of various health care professionals has been demonstrated in previous reviews $[2,3,10,11]$, its effectiveness as a standalone intervention targeted at family physicians (FP) to optimize their medication prescribing behaviour has not been previously evaluated, as far as we know, in a systematic review. Focusing on medication prescription by FPs is particularly important because they are responsible for most medication prescriptions. In Canada, FPs prescribe drugs at about $50 \%$ of office visits and are accountable for the majority of the prescriptions dispensed annually [12]. Given rising health care costs, with drugs (prescription and nonprescription) ranking as the second major contributor to healthcare spending[13, 14], facilitating and supporting evidence-based prescribing patterns is very important. To provide a more focused evaluation of the effectiveness of AD among a select group of professionals, this systematic review aims to synthesise current knowledge about the effectiveness, and the magnitude of the effect of $\mathrm{AD}$ as a stand-alone intervention at modifying drug prescription behaviour of FPs.

\section{METHODS}

Literature Search Strategy: We conducted a search of MEDLINE, EMBASE, CENTRAL, and Web of Science databases of all English language articles between January 1983 and July 2010. We used terms that mapped to Medical Subject Headings (MeSH) in combination with keyword terms as described in Table 1. We also handsearched the bibliographies of articles retrieved from the electronic search to identify additional studies.

Selection of Studies: Two authors (HC and VB) reviewed all titles and abstracts identified to select studies which met the following inclusion criteria: 1) Full-length articles describing original research; 2) Randomized controlled trial (RCT), or observational studies with a control group; 3) Studies of AD delivered to FPs; 4) AD as the sole intervention; 5) Drug prescription as the target behaviour of AD (Table 2). Figure 1 illustrates the flow of study inclusions/exclusions. The two reviewers also independently reviewed the selected studies for quality assessment and data abstraction. Any discrepancies were discussed and resolved by consensus.

Table 1. Medical Subject Headings (MeSH) terms and keywords used in electronic search strategy

\begin{tabular}{lll}
\hline \multicolumn{1}{c}{ Concept } & \multicolumn{1}{c}{ MeSH Terms } & \multicolumn{1}{c}{ Keywords } \\
\hline Academic Detailing & Education, Medical, Continuing & $\begin{array}{l}\text { Academic detailing, academically based detailing, } \\
\text { continuing medical education, public interest } \\
\text { detailing, educational outreach }\end{array}$ \\
Family Physicians & Physician & $\begin{array}{l}\text { Physicians, general practitioner, family practice, } \\
\text { family doctor, primary health care provider, general } \\
\text { practice, primary Health Care }\end{array}$ \\
Practice Patterns & Physician practice patterns & $\begin{array}{l}\text { Practice pattern, drug prescription, antibiotic } \\
\text { prescribing, drug dose calculation }\end{array}$ \\
\hline
\end{tabular}


Table 2. Inclusion and exclusion criteria for study selection

\begin{tabular}{|c|c|c|}
\hline & Inclusion Criteria & Exclusion Criteria \\
\hline Study design & RCT, observational study with control group & $\begin{array}{l}\text { Observational study without a control } \\
\text { group }\end{array}$ \\
\hline Participants & FPs in primary care setting & $\begin{array}{l}\text { specialist physicians, other healthcare } \\
\text { professionals }\end{array}$ \\
\hline Intervention & $\begin{array}{l}\mathrm{AD} \text { as a single intervention (not as part of a } \\
\text { multifaceted intervention) }\end{array}$ & $\begin{array}{l}\text { other CME, educational intervention, } \\
\text { multifaceted interventions }\end{array}$ \\
\hline Target behavior & Drug prescription & other physician practice pattern \\
\hline
\end{tabular}

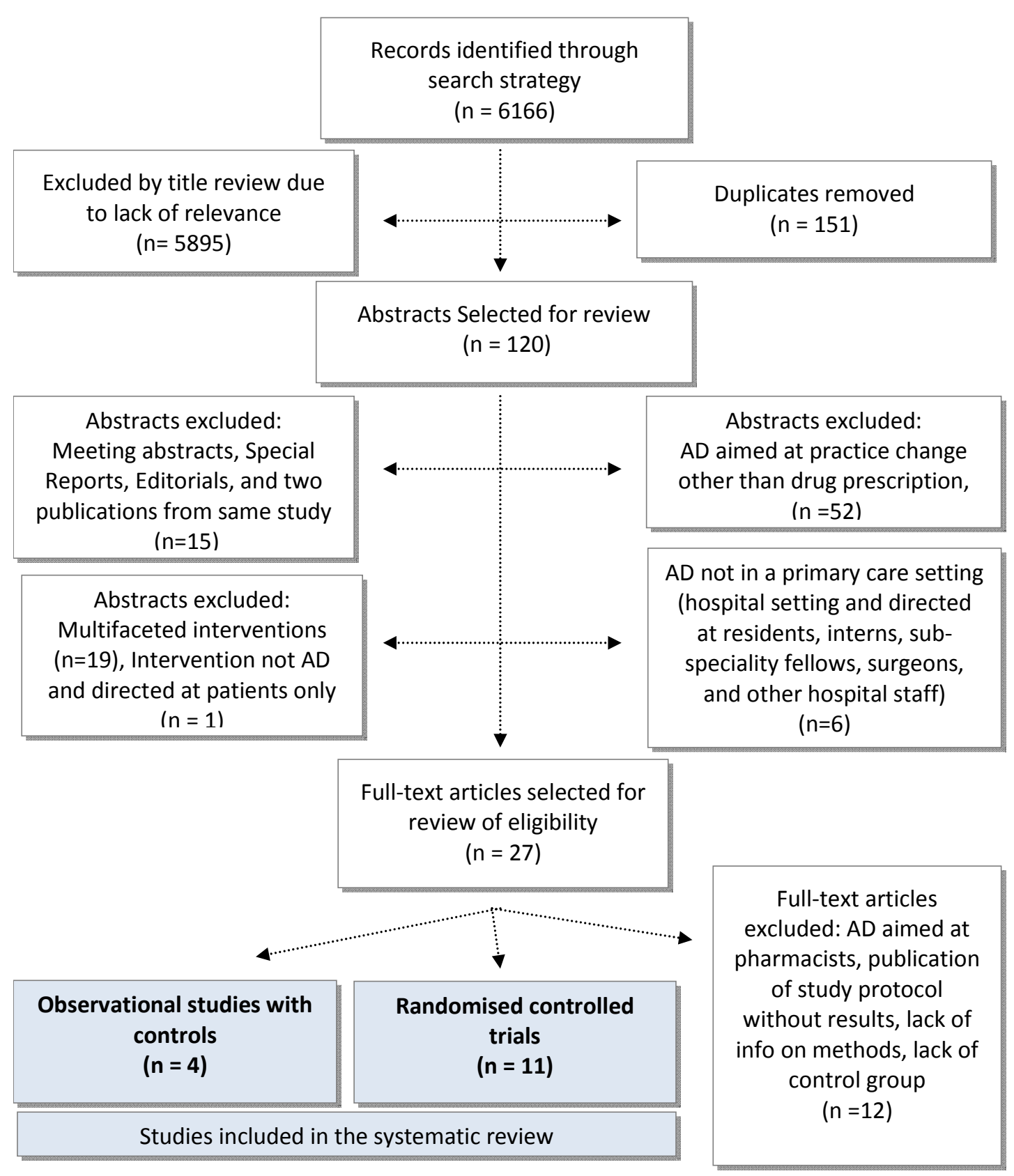

Figure 1. Flow Diagram of Studies identified in Systematic Review 
Quality Assessment of Studies: Standardized quality assessment forms were developed for the purpose of our study, using the CONSORT (Consolidated Standards of Reporting Trials) statement[15] and EPOC (Cochrane Effective Practice and Organisation of Care group) guidelines for RCTs; and the STROBE (Strengthening the Reporting of Observational studies in Epidemiology) guidelines[16] and Newcastle Ottawa Scale for observational studies)[17]. In general, studies were assessed for the quality of the study design, conduct and reporting, using the scoring criteria of: $0=$ not done or not reported, $1=$ partially done or reported, $2=$ well done and clearly reported (Appendix I).

Data Extraction: Descriptive information extracted from each study included: year of publication; country ; study design; objectives; target FP population and sample size, source and period of prescription data (e.g. administrative health data including electronic pharmacy records, survey data); information about the $\mathrm{AD}$ visits (type, number, place and whether $\mathrm{AD}$ principles were followed); control group description and whether controls received any intervention; profession and training of academic detailer; target drugs; study outcomes assessed, length of follow-up; and effect of the intervention.
Outcome Measurement: The primary outcome, evaluating the magnitude of the effect of $\mathrm{AD}$, was

the difference in relative change in prescription rate between the intervention and control groups (Table $3)$.

Secondary outcomes included the difference in absolute change in prescription rate between the intervention and control groups. Relative or absolute changes with a positive sign imply that the prescription rate increased following the intervention; whereas a negative sign implies that the prescription rates decreased.

Standardised mean differences (SMD) were also calculated to estimate the effect size, as the difference between group means for the outcome measure divided by the standard deviation of the outcome measure for the study group [18]. A Poisson distribution was assumed in studies where data were not normally distributed or where the outcome was measured as number of events. In studies where data were normally distributed and confidence intervals or Z-values were provided, we used the available $p$ values, $Z$ - values or confidence intervals to calculate the standard deviations for the computation of SMD. An effect size with a negative sign implies a lower prescription rate in the intervention group compared to the control group, which would be a desirable effect in a study trying to decrease prescription rates, and an undesirable effect in a study trying to increase prescription rates.

Table 3. Formulas

\section{Formula}

Relative Change (\%)

Difference in Relative Change
Absolute Change
Difference in Absolute
Change
Standardised Mean
Difference

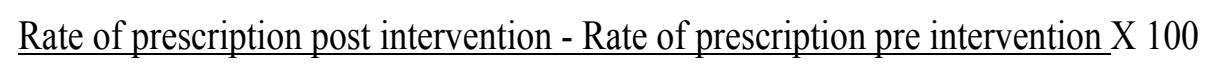

Rate of prescription pre intervention

Relative Change AD - Relative Change control

Rate of prescription post intervention - Rate of prescription pre intervention

Absolute Change AD - Absolute Change control

Difference between group means for outcome measure

Standard deviation of outcome measure for study group 
Due to heterogeneous and limited data availability, effect size could not be calculated in a homogenous way across studies; hence, a meta-analysis could not be performed.

\section{RESULTS}

Study Selection: The literature search yielded 6,166 citations, of which 120 were retained for abstract reviews, and 27 full article reviews (Figure 1). Twelve studies were excluded for the following reasons: intervention targeted at pharmacists, study protocol without results or incomplete methods description, or observational study design without a control group. The systematic review includes 15 studies: 11 RCTs and 4 observational studies $[7,19$ 32].

Description of Studies: Randomized controlled trials (RCTs): The RCTs were generally of high quality, with quality assessment scores varying from 38 to 51 out of maximum possible score of 53 (median $=48)$. Five of the 11 RCTS described results showing effectiveness, i.e. achieving a change in the direction recommended by the $\mathrm{AD}$ intervention. Two RCTs reported a positive effect on some but not all the target drugs, while 4 RCTs reported no effect from the $\mathrm{AD}$ intervention (Tables 4 and 6). Two RCTs evaluated AD aimed at increasing prescription of the target medication.

Neither study reported a statistically significant effect for the intervention[25, 33]. Five RCTs aimed at decreasing medication prescription. Of these, two studies showed a statistically significant effect for all[7, 34], and one study for some [29], of the target medications. Four studies evaluated AD aimed at increasing the prescription of some medications while decreasing others. Of these, two showed statistically significant effects for all [26, 35 ] and one study for some of the target medications[24].

Avorn et al. assessed the effectiveness of $A D$ at decreasing the use of cerebral and peripheral vasodilators, an oral cephalosporin (Cephalexin) and propoxyphene [7]. They compared the mean number of drug units prescribed per physician over a one year period before and after the intervention in groups who received $\mathrm{AD}$ and controls receiving no intervention. $\mathrm{AD}$ was effective at reducing prescription of all target drug types (the authors report a between group mean difference of 782 units for all three drugs combined, $\mathrm{p}<0.0001)$. We calculated a difference of $-14 \%$ in relative change between AD and controls; and an effect size of -7.8.

De Burgh et al. evaluated the effect of AD on reducing benzodiazepines (BDZ) prescriptions for insomnia and anxiety[22] by comparing the rate of BDZ prescriptions per 100 patient encounters with diagnoses of anxiety or insomnia. The overall rate of $\mathrm{BDZ}$ prescriptions decreased by $23.7 \%$ between pre and post- intervention surveys $(p<0.001)$ in the entire study sample, but no statistically significant differences were observed between $A D$ and controls $(p=0.2)$ in overall BDZ prescription rates or in prescription of BDZ for either anxiety or insomnia. We calculated a difference in relative change of $-7 \%$ and $-3 \%$, respectively, for anxiety and insomnia. Effect size could not be calculated.

Zwar et al. [23] evaluated the effectiveness of $\mathrm{AD}$ at decreasing repeat prescriptions of BDZ. They measured BDZ prescriptions per 100 patient encounters, for all indications, sleep problems and anxiety in the intervention group and a control group receiving $\mathrm{AD}$ on an unrelated topic. $\mathrm{A}$ decrease in BDZ prescription rates post intervention was observed in both groups, for all indications $[p=$ $0.042]$; but no statistically significant differences were detected between groups for sleep problems or anxiety. We calculated a difference in relative change between $\mathrm{AD}$ and control groups of $+10 \%$, $2 \%$ and $-22 \%$; and effect sizes of $+0.42,-0.08$ and 0.529 , for BDZ prescriptions for all indications, sleep problems, and anxiety, respectively.

Iiett et al. [24] evaluated the effectiveness of $\mathrm{AD}$ at modifying antibiotic prescriptions for upper and lower respiratory tract infections, otitis media, and urinary infections. They compared the total number of prescriptions in the AD and control groups over a three month period pre and post intervention. An overall increase in all antibiotic prescriptions was observed from pre to post intervention. However, the increase in prescription of two of the recommended drugs, doxycycline and amoxicillin $250 \mathrm{mg}$, was greater in the $\mathrm{AD}$ than control group (median number of prescriptions per $\mathrm{FP}$ increasing from 1 to 6 in $\mathrm{AD}$ vs. 1 to 2 in controls for doxycycline, $p=0.001$; and from 3 to 6 in $\mathrm{AD}$ vs. 4.5 to 7.5 in controls for amoxicillin, $\mathrm{p}=$ 0.03 respectively. Furthermore, the increase in nonrecommended drugs, Cefaclor and Roxithromycin, was less in the AD than control group (from 5.5 to 7.5 in $\mathrm{AD}$ vs. 5.5 to 10 in controls, $\mathrm{p}=0.03$ for Cefaclor, from 8.5 to 11.5 in $\mathrm{AD}$ vs. 12 to 18.5 in controls, $\mathrm{p}=0.03$ for Roxithromycin). We 
calculated a difference in relative change of $+59 \%$ and $-74 \%$; and a combined effect size of -0.51 and +2.02 , for the eight recommended and two nonrecommended antibiotics, respectively.

Ray et al. [34] evaluated the effectiveness of $\mathrm{AD}$ at decreasing the use of NSAIDs for osteoarthritis in elderly patients. The estimated intervention effect was an absolute reduction in mean duration of NSAID use of 21.3 days $(95 \% \mathrm{CI}$, 10.2 to 32.4$)$ and a relative reduction of $7 \%(95 \%$ CI, $3 \%$ to $11 \%$ ). We calculated an effect size of 3.76 .

Hall et al. [25] evaluated the effectiveness of $\mathrm{AD}$ at increasing the use of omeprazole and metronidazole for the management of $\mathrm{H}$. pylori. There was a non-significant change in prescribing of -0.02 (95\% CI: -0.12 to +0.08$)$ for Omeprazole and $-0.005 \quad(95 \% \quad \mathrm{CI}:-0.025$ to 0.015$)$ for Metronidazole. We calculated a difference in relative change of $-9 \%$ and $-5 \%$, and effect sizes of -0.4 and -0.5 , for omeprazole and metronidazole, respectively.

Van Eijk et al. [26] evaluated the effectiveness of $\mathrm{AD}$ at reducing the prescription of highly anticholinergic antidepressants for elderly people. Intent to treat analysis revealed a reduction in the rate of highly anticholinergic antidepressants in elderly people of $26 \%$ (95\% CI: - 4 to $48 \%$ ) in the individual $\mathrm{AD}$ arm and of $45 \%$ (95\% CI: 8 to $67 \%)$ in the group $\mathrm{AD}$ arm, compared with controls. The use of less anticholinergic antidepressants increased by $40 \%$ (95\% CI: 6 to $83 \%)$ in the individual AD and by $29 \%$ (95\% CI: -7 to $79 \%)$ in the group AD, compared to controls. We calculated a difference in relative change of $-47 \%$ and $+68 \%$, for highly anticholinergic and less anticholinergic antidepressants, respectively, with individual $\mathrm{AD}$ of $-59 \%$ and $+39 \%$, respectively, with group $\mathrm{AD}$.

Bernal-Delgado et al. [35] evaluated the effect of $\mathrm{AD}$ on increasing prescriptions of Diclofenac and Piroxicam, while decreasing prescriptions of Aceclofenac, Meloxicam, and Tenoxicam for osteoarthritis. The intervention led to reduced use of non-recommended drugs. Relative reductions of $25.5 \%$ in $\mathrm{AD}$ vs. $1.2 \%$ in controls were observed for Meloxicam; and relative reductions of $22.6 \%$ in $\mathrm{AD}$ vs. $14.4 \%$ in controls for Tenoxicam. We calculated a difference in relative change of $+7.49 \%$ and $+9.71 \%$; and effect sizes of +1.97 and +2.01 for the two recommended NSAIDs, and differences in relative changes of $-6.49 \%,-24.31 \%$ and
$-37.03 \%$; and effect sizes of $-1.28,-2.63$ and -8.25 for the three non-recommended NSAIDs.

Witt et al. [28] examined the effect of AD on increasing prescription of inhaled steroids and decreasing inhaled beta-2-agonists in children, as recommended in clinical guidelines for asthma. No significant short term $(\mathrm{p}=0.10)$ or long term $(\mathrm{p}=$ 0.72 ) effects of the intervention were detected for either medication. We calculated a difference in relative change of $+7 \%$ and $-2 \%$; and effect sizes of -0.09 and +0.18 for inhaled steroids and betaagonists, respectively.

Midlov et al. [29] evaluated the effect of AD on reducing prescription of $\mathrm{BDZ}$ and antipsychotic drugs in the elderly. They measured daily defined doses (DDD) dispensed over three month periods for one year after the intervention, and calculated the percent difference in the geometric mean at one year compared to baseline. There was a statistically significant reduction in prescription of medium and long acting BDZs, with a difference in relative change of $-26.63 \%$ (95\% CI:-0.03to $-46.15, \mathrm{p}<$ $0.05)$ and total BDZs $(-25.8 \%, 95 \%$ CI to- 1.32 ; $44.20, \mathrm{p}<0.05)$. No statistically significant difference was observed for antipsychotic drugs.

Simon et al. [30] evaluated the effectiveness of group and individual $\mathrm{AD}$ compared to a control group receiving printed guidelines by mail at increasing use of diuretics and beta blockers for hypertension, to improve adherence to hypertension guidelines. The percentage of new hypertension patients receiving a diuretic or beta-blocker in the first year after the intervention increased by $13 \%$ in group $\mathrm{AD}$ practices, $12.5 \%$ in individual detailing practices and $6.2 \%$ in controls. Two years following the intervention, a persistent effect of individual AD was seen, although it was not statistically significant (OR, 1.22; 95\% CI, 0.92 to1.62) but there was no longer any effect for group detailing (OR, 1.06; 95\% CI, 0.80 to1.39). We calculated a difference in relative change of $+10.9 \%$ between the individual $\mathrm{AD}$ and control group, and a difference of $+14.7 \%$ between the group $\mathrm{AD}$ and control group.

Observational studies: Four observational studies were included (Table5). All evaluated AD aimed at decreasing prescription of a target drug $[20,21,31$, 32]. Of these, 2 found $\mathrm{AD}$ to be effective [20, 21], while 2 did not [31, 32]. Quality assessment scores varied from 36 to 44 out of a possible maximum score of 47 (median score $=41.5)$. 
Atkin et al. [31] studied the effect of AD on reducing the number of concurrent medications taken by the elderly patients. No differences were found between the groups $(\mathrm{p}=0.19)$; a reduction in concurrent medication prescriptions was observed in the entire sample over the study period $(\mathrm{p}<$ 0.02), perhaps due to the introduction of copayment as a new health policy over the same period. We calculated a difference in relative change of $-9 \%$ and an effect size of -0.81 .

Peterson et al. [21] examined the effectiveness of $\mathrm{AD}$ at encouraging the use of Paracetamol (PCM) instead of NSAIDs as first line treatment for rheumatic diseases in elderly patients. Changes in daily defined doses of NSAIDs relative to PCM were evaluated. A reduction was observed in both control and intervention regions, with a significantly greater reduction within the intervention than the control region $(\mathrm{p}<0.0001)$. We calculated a difference in relative change of $-6 \%$ and an effect size of -5.24 .

Tomson et al.[32] assessed the effect of AD on reducing inhaled beta agonists and increasing inhaled steroids for asthma. The ratio of prescribed daily defined doses of inhaled beta agonists to inhaled steroids decreased significantly after the intervention in the AD area $(\mathrm{p}=0.001)$ while there was no significant change in the control area $(\mathrm{p}=0.1)$, but the difference between the two areas was not statistically significant ( $p$ value not provided), possibly due to lack of power (number of health centers in the control area $=26$ ).

Graham et al. [20] evaluated the effect of AD on reducing the prescription of selective cyclooxygenase- 2 inhibitors (COX-2) antiinflammatory medications in patients with osteoarthritis. The decrease in COX-2 prescriptions over the first 3 months post intervention was greater in the AD than in the control group ( $p=0.04)$. The effect was not sustained at 12 months $(p=0.398)$, however 3 months was the primary end point of the study. We calculated a difference in relative change of $-23 \%$ and an effect size of -0.09 .

\section{DISCUSSION}

To our knowledge, this is the first systematic review specifically examining the effectiveness of $\mathrm{AD}$ as a stand-alone intervention to optimize the prescription behaviour of FPs. This systematic review confirmed the effectiveness of $\mathrm{AD}$, with $60 \%$ of the studies reviewed showing a statistically significant change and in the desired direction in the prescription behaviour of FPs. Our study results support the use of $\mathrm{AD}$ as a strategy to promote incorporation of research findings into clinical practice or to improve compliance with clinical guidelines.

The magnitude of the effectiveness of $A D$ varied widely across studies. Lack of relevant data prohibited calculation of measures of variability associated with the difference in relative change. Thus we could not calculate a pooled estimate of the difference in relative change from the individual studies. The median between group differences in relative change among the studies reviewed was $21 \%$ (interquartile range $43.75 \%$ ) for RCTs, and $9 \%$ (interquartile range $8.5 \%$ ) for observational studies (Table 4).

The heterogeneity in method used to calculate effect sizes made it impossible to perform a metaanalysis and pool the effect size results across the studies and limited our ability to compare individual effect sizes across studies. Nonetheless, the median effect size among the studies reviewed was - 0.09 (interquartile range 2.73) (Table 6), which represents a substantive effect size. Using Cohen's criteria for effect sizes[18] in the 7 studies evaluating 11 medications where effect sizes were calculated and were positive (i.e. in the direction of the recommended change), 8 effect sizes were large, 1 was medium, and 2 were small. There are limitations to the interpretation of the effect sizes we calculated. Cohen's rule is a general rule that is used in the event of unavailability of specific criteria for clinical relevance in research results $[18$, 36]. We used a Poisson assumption to calculate effect size, when data were not normally distributed, which can lead to overestimation, especially when large effect sizes are found. However, even small effects on inappropriate prescribing may be clinically important when they affect a large number of patients or a clinically important health outcome [37]. Finally it was difficult for us to compare effect sizes based on normal and non-normal distributions [38].

Our systematic review supports the use of AD as a strategy to optimize prescribing behaviour in a variety of contexts. Specifically, $\mathrm{AD}$ has been effective at reducing or increasing prescription of medications according to recommendations. The most frequent rationale for the recommended prescription change was to reduce the risk of sideeffects (67\% of the studies), followed by improving 
cost-effectiveness $(20 \%$ of the studies). Less frequently, $\mathrm{AD}$ was used to promote implementation of clinical guidelines $(13 \%$ of studies). The rationale for the prescription change advocated in the AD intervention did not appear to influence the results of the studies, although the small number of studies evaluated did not allow this to be evaluated formally with regression analysis.

Our results complement information from other reviews $[2,3,10,11]$ that have synthesized data on the effectiveness of $\mathrm{AD}$ in different clinical contexts, including a previous Cochrane review [11]. The Cochrane review, published in 2007 [11] included RCTs evaluating the effect of AD aimed at improving clinical behaviours of a range of health care professionals (GPs, pharmacists, counter attendants, nurses, residents, dentists, etc). The authors found that $\mathrm{AD}$, with or without the addition of other interventions, can be effective at improving the practice of health care professionals, but the effect is variable. For studies where the health care outcome was measured as a dichotomous variable representing compliance with a recommended behaviour, effect was measured as the betweengroup difference in improvement in compliance with the desired behaviour [11]. They found greater improvement in compliance in the AD than control groups receiving no intervention, with a median difference of $5.0 \%$ (inter-quartile range $3.2 \%$ ) between groups. For studies where the health care outcome was a continuous variable, the relative percentage change attributable to the intervention was measured, and found a median value of $23 \%$ (inter-quartile range $27 \%$ ). The effect specifically on prescribing behaviour was only evaluated in studies looking at multifaceted interventions, of which $\mathrm{AD}$ was one component; therefore, the effect attributable to $\mathrm{AD}$ could not be evaluated. They found that the improvement in compliance with desired prescription behaviour was superior in the intervention groups with a median between group difference of $4.8 \%$ (inter-quartile range $3.5 \%$ ).

Another systematic review by Grimshaw et al. [10] evaluated various guideline dissemination and implementation strategies, including the use of $\mathrm{AD}$ as part of multifaceted educational interventions. This review, similar to the Cochrane review [11] did not focus specifically on FPs and does not provide evidence about the effectiveness of $A D$ as a stand-alone intervention. For studies measuring the process of care using a dichotomous outcome measure, the performance of care (measured as the proportion of people who received appropriate treatment) post intervention was better in the intervention group, with a median absolute difference between intervention and control group of $6 \%$ (minimum to maximum: -4.0 to $+17.4 \%$ ) for RCTs and $7.3 \%$ for observational studies (minimum to maximum: -5.6 to $16.4 \%$ ). For studies measuring the process of care using a continuous outcome variable, the median relative difference between groups in post intervention performance was $15 \%$ (minimum to maximum: $1.7 \%$ to $24 \%$ ) for RCTs and $11.3 \%$ for the single observational study. Although direct comparison of our results with those of previous systematic reviews is not possible due to differences in the interventions compared and in the outcomes used to measure effectiveness, results are consistent in confirming the effectiveness of using $\mathrm{AD}$ for health care practitioners, with effects of at least moderate magnitude.

To evaluate the magnitude of the effect of the $\mathrm{AD}$ interventions, we chose to calculate and report between-group differences in relative change from baseline as the primary outcome, and betweengroup differences in absolute change from baseline and effect size (SMD) as secondary outcomes. Changes were calculated from baseline, rather than comparing uniquely the post intervention rates in both groups, because despite the randomization, baseline rates of prescriptions differed between groups in many of the studies. Relative change was selected rather than absolute change due to the heterogeneity in the outcome measures of the individual studies, which prevented meaningful comparison of absolute rates across studies. Calculation of effect size is preferable in this circumstance; however, available data only allowed calculation in 10 of the 15 studies and the results could not be pooled in a meta-analysis because of heterogeneity in the data available for calculating effect sizes. Nevertheless, our choice of primary outcome has some disadvantages. Expressing effects as relative changes can be difficult to interpret, or even misleading, especially when baseline rates are small. In such situations, small absolute changes can lead to large relative changes. Conversely, when baseline rates are fairly large, clinically meaningful absolute changes can appear as small relative changes. Therefore, we suggest relative changes need to be interpreted in the context of the actual baseline rates. It is statistically more challenging to demonstrate effectiveness 
when comparing changes from baseline between two groups, than when comparing differences in post intervention rates[39]. We may have underestimated or overestimated the effect of $\mathrm{AD}$ reported in terms of difference in relative change in this systematic review. Regrettably, due to the nature of the studies and the availability of data, this was the only consistent and meaningful outcome measure that could be calculated across studies.

Our systematic review has provided an overview of different clinical contexts in which AD has been used to optimize prescription of medications by FPs and synthesized current evidence about its effectiveness and the magnitude of the effect. This information is of interest to health policy planners implementing or considering the implementation of $\mathrm{AD}$ programs, to medical educators and health care professionals designing $\mathrm{AD}$ interventions, as well as to researchers, professional bodies and other organizations looking for effective ways to disseminate research evidence or to incorporate clinical guidelines. Our results support the increased use of $\mathrm{AD}$ programs aimed specifically at FPs seen over the last decade in Canada and elsewhere. Such programs offer a practical alternative for FPs to stay up to date with rapidly evolving new research evidence. They provide physicians with evidence based non-biased information about incorporating research evidence in their practice based on a synthesis of the current literature.

In conclusion, $\mathrm{AD}$ has been used, as a standalone intervention to alter the prescription behaviour of FPs. This systematic review demonstrates that $\mathrm{AD}$ can be effective at optimizing prescription of medications by FPs, and that, although variable effect magnitudes were moderate in the majority of studies. This systematic review provides evidence supporting the use of $A D$ as a strategy to promote evidence-based prescription of medications or incorporation of clinical guidelines into clinical practice [4].

\section{ACKNOWLEDGEMENT}

Harpreet Chhina was supported by a stipend from Canadian Arthritis Network. Authors had no conflict of interest regarding the content of this article.

\section{REFERENCES}

1. Davis D, O'Brien MAT, Freemantle N, Wolf FM, Mazmanian P, Taylor-Vaisey A. Impact of formal continuing medical education - Do conferences, workshops, rounds, and other traditional continuing education activities change physician behavior or health care outcomes? Journal of the American Medical Association, 1999. 282(9): 867-874.

2. Davis DA, Thomson MA, Oxman AD, Haynes RB. Changing Physician Performance - a Systematic Review of the Effect of Continuing MedicalEducation Strategies. Jama-Journal of the American Medical Association, 1995. 274(9): 700-705.

3. Bloom, B.S. Effects of continuing medical education on improving physician clinical care and patient health: A review of systematic reviews. International Journal of Technology Assessment in Health Care, 2005. 21(03): 380 .

4. Soumerai, S.B. and J. Avorn. Principles of Educational Outreach ('Academic Detailing') to Improve Clinical Decision Making. Journal of the American Medical Association, 1990. 263(4): 549556.

5. Allen M, Ferrier S, O'Connor N, Fleming I. Family physicians' perceptions of academic detailing: a quantitative and qualitative study. BMC Medical Education, 2007. 7: 36.

6. Beilby, J.J. and C.A. Silagy. Trials of providing costing information to general practitioners: a systematic review. Medical Journal of Australia, 1997. 167(2): 89-92.

7. Avorn, J. and S.B. Soumerai. Improving drugtherapy decisions through educational outreach. A randomized controlled trial of academically based "detailing". The New England journal of medicine, 1983. 308(24): 1457-1463.

8. Bacovsky R, Maclure M, Nguyen A, Lopatka H Canadian Academic Detailing Collaboration: evaluating processes and outcomes of academic detailing. Canadian Pharmacists Journal, 2006. 139(2): 54-57.

9. Allen, M., et al., Funding for continuous medical education. Canadian Medical Association Journal, 2008.

10. Grimshaw JM, Thomas RE, MacLennan G, Fraser C, Ramsay CR, Vale L. Effectiveness and efficiency of guideline dissemination and implementation strategies. Health technology assessment, 2004. $8(6): 1$.

11. O'Brien MA, Rogers S, Jamtvedt G, Oxman AD, Odgaard-Jensen J, Kristoffersen DT. Educational outreach visits: effects on professional practice and health care outcomes. Cochrane Database of Systematic Reviews, 2007(4): CD000409- 
12. Lexchin, J. Improving the appropriateness of physician prescribing. International Journal of Health Services, 1998. 28(2): 253-267.

13. Morgan, S. Canadian prescription drug costs surpass 18 billion dollars. CMAJ: Canadian Medical Association Journal $=$ Journal De L'association Medicale Canadienne, 2005. 172(10): 1323-1324.

14. Constant, A., et al., Research Synthesis On Cost Drivers In The Health Sector And Proposed Policy Options, Canadian Health Services Research Foundation: Ottowa, Canada.

15. Schulz, K.F., D.G. Altman, and D. Moher, CONSORT 2010 statement: updated guidlines for reporting paralle group randomised trials. Annals of Internal Medicine. 152(11): 1.

16. Von Elm, E., et al., The Strengthening the Reporting of Observational Studies in Epidemiology (STROBE) statement: guidelines for reporting observational studiesJournal of Clinical epidemiology, 2008. 61(4): 344-349.

17. Wells GA, S.B., O'Connell D, Peterson J, Welch V, Losos M. The Newcastle-Ottawa Scale (NOS) for assessing the quality if nonrandomized studies in meta-analyses. [cited 2010 June]; Available from: http://www.ohri.ca/programs/clinical_epidemiology/

18. Cohen, J. Statistical power analysis for the behavioral sciences. 1988, NJ: Hillsdale.

19. Ray WA, Stein CM, Byrd V, Shorr R, Pichert JW, Gideon $\mathrm{P}$ Educational program for physicians to reduce use of non-steroidal anti-inflammatory drugs among community-dwelling elderly persons: a randomized controlled trial. Medical care, 2001. 39(5): 425-435.

20. Graham SD, Hartzema AG, Sketris IS, Winterstein AG Effect of an academic detailing intervention on the utilization rate of cyclooxygenase- 2 inhibitors in the elderly. Annals of Pharmacotherapy, 2008. 42(6): 749-756.

21. . Peterson GM, Bergin JK, Nelson BJ, Stanton LA Improving drug use in rheumatic disorders. Journal of clinical pharmacy and therapeutics, 1996. 21(4): 215-220.

22. De Burgh S, Mant A, Mattick R, Donnelley N, Hall $\mathrm{W}$, Bridges-Webb C A controlled trial of educational visiting to improve Benzodiazipine prescribing in general practice. Australian Journal of public health, 1995. 19(2): 142-148.

23. Zwar NA, Wolk J, Gordon JJ, SansonFisher RW. Benzodiazepine prescribing by GP registrars. A trial of educational outreach. Australian Family Physician, 2000. 29(11): 1104-1107.

24. Ilett KF, Johnson S, Greenhill G, Mullen L, Brockis J, Golledge CL Modification of general practitioner prescribing of antibiotics by use of a therapeutics adviser (academic detailer). British journal of clinical pharmacology, 2000. 49(2): 168-173.
25. Hall L, Eccles M, Barton R, Steen N, Campbell M Is untargeted outreach visiting in primary care effective? A pragmatic randomized controlled trial. Journal of public health medicine, 2001. 23(2): 109113.

26. Van Eijk ME, Avorn J, Porsius AJ, de Boer A Reducing prescribing of highly anticholinergic antidepressants for elderly people: randomised trial of group versus individual academic detailing. British Medical Journal, 2001. 322(7287): 654-657.

27. BernalDelgado E, GaleoteMayor M, PradasArnal F, PeiroMoreno S Evidence based educational outreach visits: effects on prescriptions of non-steroidal antiinflammatory drugs. Journal of epidemiology and community health, 2002. 56(9): 653-658.

28. Witt K, Knudsen E, Ditlevsen S, Hollnagel $H$ Academic detailing has no effect on prescribing of asthma medication in Danish general practice: a 3year randomized controlled trial with 12-monthly follow-ups. Family practice, 2004. 21(3): 248-253.

29. Midlov P, Bondesson A, Eriksson T, Nerbrand C, Hoglund P Effects of educational outreach visits on prescribing of benzodiazepines and antipsychotic drugs to elderly patients in primary health care in southern Sweden. Family practice, 2006. 23(1): 6064.

30. Simon SR, Majumdar SR, Prosser LA, SalemSchatz S, Warner C, Kleinman K. Group versus individual academic detailing to improve the use of antihypertensive medications in primary care: a cluster-randomized controlled trial. The American Journal of Medicine, 2005. 118(5):521-528.

31. Atkin PA, Ogle SJ, Finnegan TP, Shenfield GM Influence of "academic detailing" on prescribing for elderly patients. Health Promot J Aust, 1996. 6(3):14-20.

32. Tomson Y, Hasselstrom J, Tomson G, Aberg H Asthma education for Swedish primary care physicians--a study on the effects of "academic detailing" on practice and patient knowledge. European journal of clinical pharmacology, 1997. 53(3-4): 191-196.

33. Simon SR, Majumdar SR, Prosser LA, SalemSchatz $\mathrm{S}$, Warner C, Kleinman K, Group versus individual academic detailing to improve the use of antihypertensive medications in primary care: a cluster-randomized controlled trial. American Journal of Medicine, 2005. 118(5): 521-528.

34. Ray WA, Stein CM, Byrd V, Shorr R, Pichert JW, Gideon $\mathrm{P}$ Educational program for physicians to reduce use of non-steroidal anti-inflammatory drugs among community-dwelling elderly persons - A randomized controlled trial. Medical care, 2001. 39(5): 425-435.

35. BernalDelgado E, GaleoteMayor M, PradasArnal F, PeiroMoreno S Evidence based educational outreach visits: effects on prescriptions of non-steroidal anti- 
inflammatory drugs. Journal of epidemiology and community health, 2002. 56(9): 653-658.

36. Volker, M.A., Reporting effect size estimates in school psychology research. Psychology in the Schools, 2006. 43(6): 653-672.

37. Mason, J., et al., When is it cost-effective to change the behavior of health professionals? Journal of American Medical Association, 2001. 286(23): 2988-2992.
38. Coe, R. It's the Effect Size, Stupid; What effect size is and why it is important. in Annual Conference of the British Educational Research Association. 2002.

39. Bland, J.M. and D.G. Altman, Comparisons against baseline within randomised groups are often used and can be highly misleading. Trials. 12: 264. 
J Pharm Pharm Sci (www.cspsCanada.org) 16(4) 511 - 529, 2013

Table 4. Descriptive Table Randomised Control Trials

\begin{tabular}{|c|c|c|c|c|c|c|c|c|c|c|}
\hline $\begin{array}{l}\text { Author } \\
\text { Year } \\
\text { Country }\end{array}$ & $\begin{array}{c}\text { Target } \\
\text { prescription } \\
\text { change }\end{array}$ & $\begin{array}{l}\text { Rationale for } \\
\text { target } \\
\text { prescription } \\
\text { change }\end{array}$ & $\begin{array}{l}\text { Type of AD } \\
\text { visits }\end{array}$ & $\begin{array}{l}\text { No. of } \\
\text { AD } \\
\text { visits }\end{array}$ & $\begin{array}{l}\text { Sample } \\
\text { size }^{*}\end{array}$ & $\begin{array}{c}\text { Academic } \\
\text { detailer }\end{array}$ & $\begin{array}{l}\text { Intervention } \\
\text { for control } \\
\text { group }\end{array}$ & $\begin{array}{l}\text { Primary } \\
\text { outcome }\end{array}$ & Analysis & $\begin{array}{c}\text { Quality } \\
\text { score } \\
(0-53)\end{array}$ \\
\hline $\begin{array}{l}\text { Avorn } \\
1983 \\
\text { USA }\end{array}$ & $\begin{array}{l}\text { Reduce use of: } \\
\text { 1) Propoxyphene } \\
\text { 2) Cerebral \& } \\
\text { peripheral } \\
\text { vasodilators } \\
\text { 3) Cephalexin }\end{array}$ & $\begin{array}{l}\text { Lack of evidence } \\
\text { for efficacy }(1 \& 2) \text {; } \\
\text { To reduce side } \\
\text { effects }(1 \& 2) ; \\
\text { To improve cost } \\
\text { effectiveness } \\
\text { (3) }\end{array}$ & Individual & 2 & 281 & Pharmacist & None & $\begin{array}{l}\text { change in mean } \\
\text { number of drug } \\
\text { units prescribed } \\
\text { per physician } \\
\text { over } 1 \text { yr before } \\
\text { and after } \\
\text { intervention }\end{array}$ & $\begin{array}{l}\text { Multi-variable } \\
\text { regression model } \\
\text { controlling for pre } \\
\text { intervention Rx } \\
\text { rate among } \\
\text { individual } \\
\text { physicians and } \\
\text { prescribing trends } \\
\text { in control group. }\end{array}$ & 48 \\
\hline $\begin{array}{l}\text { De Burgh } \\
1995 \\
\text { Australia }\end{array}$ & $\begin{array}{l}\text { Reduce BDZ Rx } \\
\text { for anxiety and } \\
\text { insomnia }\end{array}$ & $\begin{array}{l}\text { To reduce risk of } \\
\text { side-effects }\end{array}$ & Individual & 1 & 286 & $\begin{array}{c}\text { Three } \\
\text { medical staff } \\
\& \text { pharmacist }\end{array}$ & None & $\begin{array}{c}\text { Rx rate per } \\
100 \mathrm{pt} \\
\text { encounters with } \\
\text { diagnoses of } \\
\text { anxiety or } \\
\text { insomnia }\end{array}$ & $\begin{array}{l}\text { Encounter based } \\
\text { analysis } \\
\text { controlling for } \\
\text { patient, doctor } \\
\text { and practice } \\
\text { characteristics. }\end{array}$ & 46 \\
\hline $\begin{array}{c}\text { Zwar } \\
2000 \\
\text { Australia }\end{array}$ & $\begin{array}{l}\text { Reduce repeat Rx } \\
\text { of BDZ for } \\
\text { anxiety, insomnia } \\
\text { and all indications }\end{array}$ & $\begin{array}{l}\text { To reduce risk of } \\
\text { side-effects and } \\
\text { dependence }\end{array}$ & Individual & 1 & 157 & FP & $\begin{array}{l}\mathrm{AD} \text { on } \\
\text { unrelated } \\
\text { topic }\end{array}$ & $\begin{array}{c}\text { Mean rate of } \\
\text { BDZ Rx per } \\
\text { 100encounters } \\
\text { with diagnoses } \\
\text { of anxiety, } \\
\text { sleep disorders } \\
\text { and all } \\
\text { indications }\end{array}$ & $\begin{array}{c}\text { Repeated measure } \\
\text { ANOVA } \\
\text { comparing results } \\
\text { of pre AD survey } \\
\text { with surveys at } 6 \\
\text { and } 12 \text { months } \\
\text { post AD. }\end{array}$ & 40 \\
\hline $\begin{array}{l}\text { Author } \\
\text { Year } \\
\text { Country }\end{array}$ & $\begin{array}{c}\text { Target } \\
\text { prescription } \\
\text { change }\end{array}$ & $\begin{array}{l}\text { Rationale for } \\
\text { target } \\
\text { prescription } \\
\text { change }\end{array}$ & $\begin{array}{l}\text { Type of AD } \\
\text { visits }\end{array}$ & $\begin{array}{l}\text { No. of } \\
\text { AD } \\
\text { visits }\end{array}$ & $\begin{array}{l}\text { Sample } \\
\text { size }^{*}\end{array}$ & $\begin{array}{c}\text { Academic } \\
\text { detailer }\end{array}$ & $\begin{array}{l}\text { Intervention } \\
\text { for control } \\
\text { group }\end{array}$ & $\begin{array}{l}\text { Primary } \\
\text { outcome }\end{array}$ & Analysis & $\begin{array}{c}\text { Quality } \\
\text { score } \\
(0-53)\end{array}$ \\
\hline $\begin{array}{c}\text { Iiett } \\
2000 \\
\text { Australia }\end{array}$ & $\begin{array}{l}\text { Increase Rx of: } \\
\text { Amoxycillin with } \\
\text { or without } \\
\text { clavulinic acid, }\end{array}$ & $\begin{array}{l}\text { To Reduce risk-of } \\
\text { side effects and } \\
\text { improve cost } \\
\text { effectiveness }\end{array}$ & Individual & 1 & 112 & Pharmacist & None & $\begin{array}{l}\text { Total number } \\
\text { of } \mathrm{Rx} \text { per FP } \\
\text { over a } 3 \text { month } \\
\text { period }\end{array}$ & $\begin{array}{l}\text { Wilcoxon's 2- } \\
\text { sided rank sum } \\
\text { test for between } \\
\text { and within group }\end{array}$ & 38 \\
\hline
\end{tabular}


Cephalexin,

Doxycycline,

Erythromycin,

Penicillin,

Trimethoprim;

Decrease Rx of:

Cefaclor,

Roxithromycin

Ray Reduce Rx

2001 NSAIDS for

USA osteoarthritis in

elderly

population.
To reduce risk of

side-effects, esp.

GI complications

Individual

1

220

Physician
educator

None

Mean no. of

days of

prescription

NSAIDS

dispensed over

$1 \mathrm{yr}$ period per

NSAID user
Relative and absolute change in NSAID use over one year period before and after intervention.

Difference in change between

AD \& control groups.

\begin{tabular}{|c|c|c|c|c|c|c|c|c|c|c|}
\hline $\begin{array}{l}\text { Author } \\
\text { Year } \\
\text { Country }\end{array}$ & $\begin{array}{c}\text { Target } \\
\text { prescription } \\
\text { change }\end{array}$ & $\begin{array}{c}\text { Rationale for } \\
\text { target } \\
\text { prescription } \\
\text { change } \\
\end{array}$ & $\begin{array}{l}\text { Type of AD } \\
\text { visits }\end{array}$ & $\begin{array}{l}\text { No. of } \\
\text { AD } \\
\text { visits }\end{array}$ & $\begin{array}{c}\text { Sample } \\
\text { size* }\end{array}$ & $\begin{array}{l}\text { Academic } \\
\text { detailer }\end{array}$ & $\begin{array}{l}\text { Intervention } \\
\text { for control } \\
\text { group }\end{array}$ & $\begin{array}{l}\text { Primary } \\
\text { outcome }\end{array}$ & Analysis & $\begin{array}{l}\text { Quality } \\
\text { score } \\
(0-53)\end{array}$ \\
\hline $\begin{array}{l}\text { Hall } \\
2001 \\
\text { UK }\end{array}$ & $\begin{array}{c}\text { Increase Rx of } \\
\text { Metronidazole \& } \\
\text { Omeprazole for } \\
\text { H. pylori }\end{array}$ & $\begin{array}{c}\text { To improve } \\
\text { quality of care and } \\
\text { health outcomes } \\
\text { (by reducing risk } \\
\text { of peptic ulcers) } \\
\text { and cost savings }\end{array}$ & Individual & 1 & 76 & Pharmacist & None & $\begin{array}{l}\text { Mean dose } \\
\text { units } \\
\text { prescribed, per } \\
\text { quarter, per } \\
\text { patient }\end{array}$ & $\begin{array}{c}\text { Analysis of } \\
\text { overall usage of } \\
\text { drugs over } 12 \\
\text { month periods } \\
\text { before and after } \\
\text { intervention, } \\
\text { using multilevel } \\
\text { mixed modelling } \\
\text { taking into } \\
\text { account repeated } \\
\text { measures. }\end{array}$ & 51 \\
\hline
\end{tabular}




$\begin{array}{cc}\text { Van Eijk } & \text { Reduce Rx of } \\ 2001 & \text { highly } \\ \text { Netherlan } & \text { anticholinergic; } \\ \text { ds } & \text { Increase Rx of } \\ & \text { less } \\ & \text { anticholinergic } \\ & \text { antidepressants in } \\ & \text { elderly people } \\ & (\text { age } \geq 60)\end{array}$

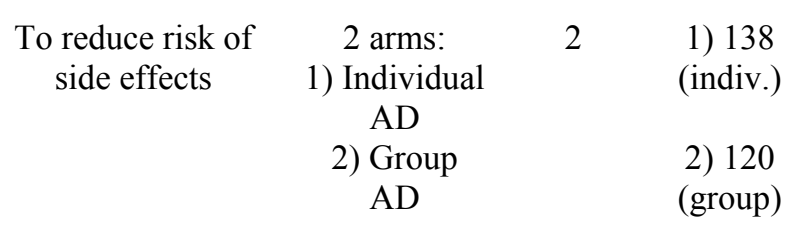

FP

\begin{tabular}{|c|c|c|}
\hline None & $\begin{array}{c}\text { Rate of incident } \\
\text { Rx of highly or } \\
\text { less } \\
\text { anticholinergic } \\
\text { antidepressants } \\
\text { per } 1000 \\
\text { person years in } \\
\text { people aged } \geq \\
60 \text { yrs }\end{array}$ & $\begin{array}{l}\text { Poisson } \\
\text { regression model } \\
\text { to estimate rate } \\
\text { ratio of starting } \\
\text { highly and less } \\
\text { anticholinergic } \\
\text { antidepressants in } \\
\text { each AD group } \\
\text { compared to } \\
\text { control group }\end{array}$ \\
\hline
\end{tabular}

\begin{tabular}{|c|c|c|c|c|c|c|c|c|c|c|}
\hline $\begin{array}{c}\text { Author } \\
\text { Year } \\
\text { Country }\end{array}$ & $\begin{array}{c}\text { Target } \\
\text { prescription } \\
\text { change }\end{array}$ & $\begin{array}{l}\text { Rationale for } \\
\text { target } \\
\text { prescription } \\
\text { change }\end{array}$ & $\begin{array}{c}\text { Type of AD } \\
\text { visits }\end{array}$ & $\begin{array}{l}\text { No. of } \\
\text { AD } \\
\text { visits }\end{array}$ & $\begin{array}{c}\text { Sample } \\
\text { size }^{*}\end{array}$ & $\begin{array}{c}\text { Academic } \\
\text { detailer }\end{array}$ & $\begin{array}{l}\text { Intervention } \\
\text { for control } \\
\text { group }\end{array}$ & $\begin{array}{l}\text { Primary } \\
\text { outcome }\end{array}$ & Analysis & $\begin{array}{c}\text { Quality } \\
\text { score } \\
(0-53)\end{array}$ \\
\hline $\begin{array}{c}\text { Bernal } \\
\text { Delgado } \\
2001 \\
\text { Spain }\end{array}$ & $\begin{array}{l}\text { NSAIDs for OA. } \\
\text { Increase Rx of: } \\
\text { Diclofenac, } \\
\text { Piroxicam; } \\
\text { Decrease Rx of: } \\
\text { Aceclofenac, } \\
\text { Meloxicam, } \\
\text { Tenaxicam }\end{array}$ & $\begin{array}{l}\text { To improve cost } \\
\text { effectiveness }\end{array}$ & Group & 1 & 104 & Pharmacist & None & $\begin{array}{c}\text { Number of } \\
\text { prescriptions of } \\
\text { each type of } \\
\text { NSAID per FP } \\
\text { during } 6 \text { month } \\
\text { period before } \\
\text { and after } \\
\text { intervention }\end{array}$ & $\begin{array}{l}\text { Relative change } \\
\text { (and } 95 \% \mathrm{CI} \text { ) in } \\
\text { rate of Rx of each } \\
\text { NSAID over } 6 \\
\text { months before } \\
\text { and after } \\
\text { intervention, in } \\
\text { AD and control } \\
\text { groups. }\end{array}$ & 49 \\
\hline $\begin{array}{c}\text { Witt } \\
2004 \\
\text { Denmark }\end{array}$ & $\begin{array}{c}\text { Increase Rx of } \\
\text { inhaled steroids } \\
\text { and decrease Rx } \\
\text { of Beta-agonists } \\
\text { for asthma in } \\
\text { children }<16 \\
\text { years. }\end{array}$ & $\begin{array}{l}\text { To improve } \\
\text { compliance with } \\
\text { clinical guidelines } \\
\text { for asthma } \\
\text { medication }\end{array}$ & Individual & 1 & 185 & FP & $\begin{array}{c}\text { Postal } \\
\text { distribution of } \\
\text { asthma } \\
\text { medication } \\
\text { guidelines }\end{array}$ & $\begin{array}{l}\text { Number of } \\
\text { DDD; of } \\
\text { steroids or } \\
\text { beta-agonists } \\
\text { per child per } \\
\text { practice }\end{array}$ & $\begin{array}{c}\text { Mixed model } \\
\text { adjusted for } \\
\text { seasonal variation } \\
\text { and general trends }\end{array}$ & 48 \\
\hline
\end{tabular}




\begin{tabular}{|c|c|c|c|c|c|c|c|c|c|c|}
\hline $\begin{array}{l}\text { Midlov } \\
2005 \\
\text { Sweden }\end{array}$ & $\begin{array}{c}\text { Decrease Rx of } \\
\text { BDZ and } \\
\text { antipsychotic } \\
\text { drugs to elderly } \\
\text { people } \geq 65 \text { years }\end{array}$ & $\begin{array}{l}\text { To reduce risk of } \\
\text { side effects }\end{array}$ & Group & 2 & 54 & $\begin{array}{c}\text { FP \& } \\
\text { pharmacist }\end{array}$ & None & $\begin{array}{l}\text { Mean number } \\
\text { of DDDi of } \\
\text { BDZ or } \\
\text { Antipsychotic } \\
\text { drugs }\end{array}$ & $\begin{array}{l}\text { Differences in } \\
\text { geometric mean } \\
\text { between active } \\
\text { and control } \\
\text { groups were } \\
\text { calculated using a } \\
\text { mixed model } \\
\text { (group by period } \\
\text { interaction, fixed } \\
\text { effects; and } \\
\text { practices as } \\
\text { random effects). }\end{array}$ & 43 \\
\hline $\begin{array}{l}\text { Author } \\
\text { Year } \\
\text { Country }\end{array}$ & $\begin{array}{c}\text { Target } \\
\text { prescription } \\
\text { change }\end{array}$ & $\begin{array}{l}\text { Rationale for } \\
\text { target } \\
\text { prescription } \\
\text { change }\end{array}$ & $\begin{array}{l}\text { Type of AD } \\
\text { visits }\end{array}$ & $\begin{array}{c}\text { No. of } \\
\text { AD } \\
\text { visits }\end{array}$ & $\begin{array}{l}\text { Sample } \\
\text { size* }^{*}\end{array}$ & $\begin{array}{l}\text { Academic } \\
\text { detailer }\end{array}$ & $\begin{array}{c}\text { Intervention } \\
\text { for control } \\
\text { group }\end{array}$ & $\begin{array}{l}\text { Primary } \\
\text { outcome }\end{array}$ & Analysis & $\begin{array}{c}\text { Quality } \\
\text { score } \\
(0-53)\end{array}$ \\
\hline
\end{tabular}

Abbreviations: Rx - prescription, NA - not available, FP - Family Physician; BDZ - Benzodiazepines, NSAIDS - Non Steroidal Anti-inflammatory Drugs, PCM - Paracetamol, COX-2 - Cyclooxygenase, GEE - Generalised Estimating Equations

* sample size of physicians in both control and AD group, $\bullet$ No. of GP practices (no. of patients not provided), ¡Daily defined doses. 


\begin{tabular}{|c|c|c|c|c|c|c|c|c|c|c|c|}
\hline $\begin{array}{l}\text { Author } \\
\text { Year } \\
\text { Country }\end{array}$ & $\begin{array}{c}\text { Target } \\
\text { prescription } \\
\text { change }\end{array}$ & $\begin{array}{c}\text { Rationale for } \\
\text { target } \\
\text { behaviour }\end{array}$ & $\begin{array}{l}\text { Type of } \\
\text { AD visits }\end{array}$ & $\begin{array}{l}\text { Number } \\
\text { of visits }\end{array}$ & $\begin{array}{c}\text { Sample } \\
\text { size }\end{array}$ & $\begin{array}{c}\text { Academic } \\
\text { detailer }\end{array}$ & $\begin{array}{c}\text { Description of } \\
\text { control group's } \\
\text { characteristics } \\
\text { and intervention } \\
\end{array}$ & Primary Outcome & Analysis & $\begin{array}{c}\text { Effectiveness of AD, as reported in } \\
\text { publication }\end{array}$ & $\begin{array}{c}\text { Quality } \\
\text { score } \\
0-47\end{array}$ \\
\hline $\begin{array}{l}\text { Atkin } \\
1996 \\
\text { Australia }\end{array}$ & $\begin{array}{l}\text { To reduce } \\
\text { number of } \\
\text { concurrent } \\
\text { medications for } \\
\text { elderly }\end{array}$ & $\begin{array}{l}\text { Reduce risk of } \\
\text { adverse drug } \\
\text { reactions }\end{array}$ & Individual & 2 & $\begin{array}{l}59 \mathrm{AD} \\
47 \\
\text { Control }\end{array}$ & Pharmacist & $\begin{array}{l}\text { Geographically } \\
\text { distinct area with } \\
\text { similar } \\
\text { demographic } \\
\text { characteristics; no } \\
\text { intervention } \\
\text { received }\end{array}$ & $\begin{array}{l}\text { Mean no. of } \\
\text { medications } \\
\text { prescribed } \\
\text { concurrently per } \\
\text { elderly patient who } \\
\text { visited FP in } 12 \\
\text { months post } \\
\text { intervention. }\end{array}$ & $\begin{array}{l}\text { Repeated measure ANOVA } \\
\text { evaluating differences in } \\
\text { mean per-doctor prescribing } \\
\text { between the groups; } \\
\text { differences in prescribing } \\
\text { over time; and group/time } \\
\text { interaction. }\end{array}$ & $\begin{array}{l}\text { No significant difference between the two } \\
\text { groups at any data collection point } \\
(\mathrm{df}=1, \mathrm{~F}=1.72, \mathrm{p}=0.19) ; \text { Significant } \\
\text { reduction }(\mathrm{df}=3, \mathrm{~F}=3.78, \mathrm{p}<0.02) \text { in } \\
\text { prescribing in both groups probably due to } \\
\text { introduction of co-payment. }\end{array}$ & 42 \\
\hline $\begin{array}{l}\text { Peterson } \\
1996 \\
\text { Australia }\end{array}$ & $\begin{array}{l}\text { To reduce Rx of } \\
\text { NSAIDs and } \\
\text { increase Rx of } \\
\text { PCM for } \\
\text { rheumatic } \\
\text { diseases in } \\
\text { elderly }\end{array}$ & $\begin{array}{l}\text { Reduce risk of } \\
\text { side-effects } \\
\text { (gastric } \\
\text { bleeding) }\end{array}$ & Individual & 1 & $\begin{array}{l}250 \mathrm{AD} \\
\text { control } \\
\text { group } \\
\text { sample } \\
\text { size NA }\end{array}$ & Pharmacist & $\begin{array}{l}\text { Geographically } \\
\text { distinct area with } \\
\text { similar } \\
\text { demographic } \\
\text { characteristics; no } \\
\text { intervention } \\
\text { received. }\end{array}$ & $\begin{array}{l}\text { Ratio of NSAID to } \\
\text { PCM in DDD units }\end{array}$ & $\begin{array}{l}\text { Change over time within and } \\
\text { between study areas were } \\
\text { compared using a normal } \\
\text { approximation to binomial } \\
\text { distribution. }\end{array}$ & $\begin{array}{l}\text { Statistically significant effect } \\
\text { Reduction post intervention observed in } \\
\text { control }(Z=7.78, p<0.0001) \text { and } \\
\text { intervention }(Z=14.42, p<0.0001) \text {, with } \\
\text { a significant between group difference ( } \mathrm{Z} \\
=5.22, \mathrm{p}<0.0001) \text {. }\end{array}$ & 36 \\
\hline $\begin{array}{l}\text { Tomson } \\
1997 \\
\text { Sweden }\end{array}$ & $\begin{array}{l}\text { To decrease Rx } \\
\text { of inhaled } \beta \text { - } \\
\text { agonists; and } \\
\text { increase inhaled } \\
\text { steroids for } \\
\text { asthma }\end{array}$ & $\begin{array}{l}\text { Improve } \\
\text { compliance } \\
\text { with asthma } \\
\text { guidelines }\end{array}$ & Group & 2 & $\begin{array}{l}70 \mathrm{AD} \\
26 \\
\text { Control }\end{array}$ & $\begin{array}{l}\text { Pharmacologist } \\
\text { and pharmacist }\end{array}$ & $\begin{array}{l}\text { No intervention } \\
\text { received }\end{array}$ & $\begin{array}{l}\text { Ratio of inhaled } \\
\beta \text { - agonists to inhaled } \\
\text { steroids in DDD units }\end{array}$ & $\begin{array}{l}\text { Mann-Whitney's U test to } \\
\text { analyse difference in changes } \\
\text { between groups \& Wilcoxon } \\
\text { signed-rank test for changes } \\
\text { within groups }\end{array}$ & $\begin{array}{l}\text { No statistically significant between group } \\
\text { difference. } \\
\text { Within group change observed in AD but } \\
\text { not control group. }\end{array}$ & 41 \\
\hline $\begin{array}{l}\text { Graham } \\
2008 \\
\text { Canada }\end{array}$ & $\begin{array}{l}\text { To reduce Rx of } \\
\text { COX-2 for OA } \\
\text { in elderly } \\
\text { patients }\end{array}$ & $\begin{array}{l}\text { Improve Cost } \\
\text { effectiveness }\end{array}$ & Individual & 1 & $\begin{array}{l}231 \mathrm{AD} \\
265 \\
\text { Control }\end{array}$ & $\begin{array}{l}\text { Pharmacist } \\
(\mathrm{n}=2) \text { or nurse } \\
(\mathrm{n}=1)\end{array}$ & $\begin{array}{l}\text { Differences in FP } \\
\text { and patients } \\
\text { characteristics } \\
\text { adjusted for in } \\
\text { analysis. No } \\
\text { intervention } \\
\text { received. }\end{array}$ & $\begin{array}{l}\text { Rate of COX-2 Rx in } \\
\text { DDD per elderly pt in } \\
\text { each FP practice over } \\
3 \text { months (Primary } \\
\text { endpoint), follow-up } \\
\text { until } 12 \text { months } \\
\text { (Secondary endpoint) } \\
\text { post intervention }\end{array}$ & $\begin{array}{l}\text { GEE model accounting for } \\
\text { repeated measures over time, } \\
\text { and propensity score to adjust } \\
\text { for differences in FP and } \\
\text { patient characteristics }\end{array}$ & $\begin{array}{l}\text { Yes (first } 3 \text { months post intervention only) } \\
\text { Greater decrease in AD group over first } 3 \\
\text { months [between group difference }(95 \% \\
\text { CI) of } 0.76(0.037 ; 1.48) \mathrm{DDD} / \mathrm{pt} ; \mathrm{Z}=2.06 \text {; } \\
\mathrm{p}=0.04] \text {. } \\
\text { No significant difference at } 12 \text { months. }\end{array}$ & 44 \\
\hline
\end{tabular}


Table 6. Results of studies included in the systematic review

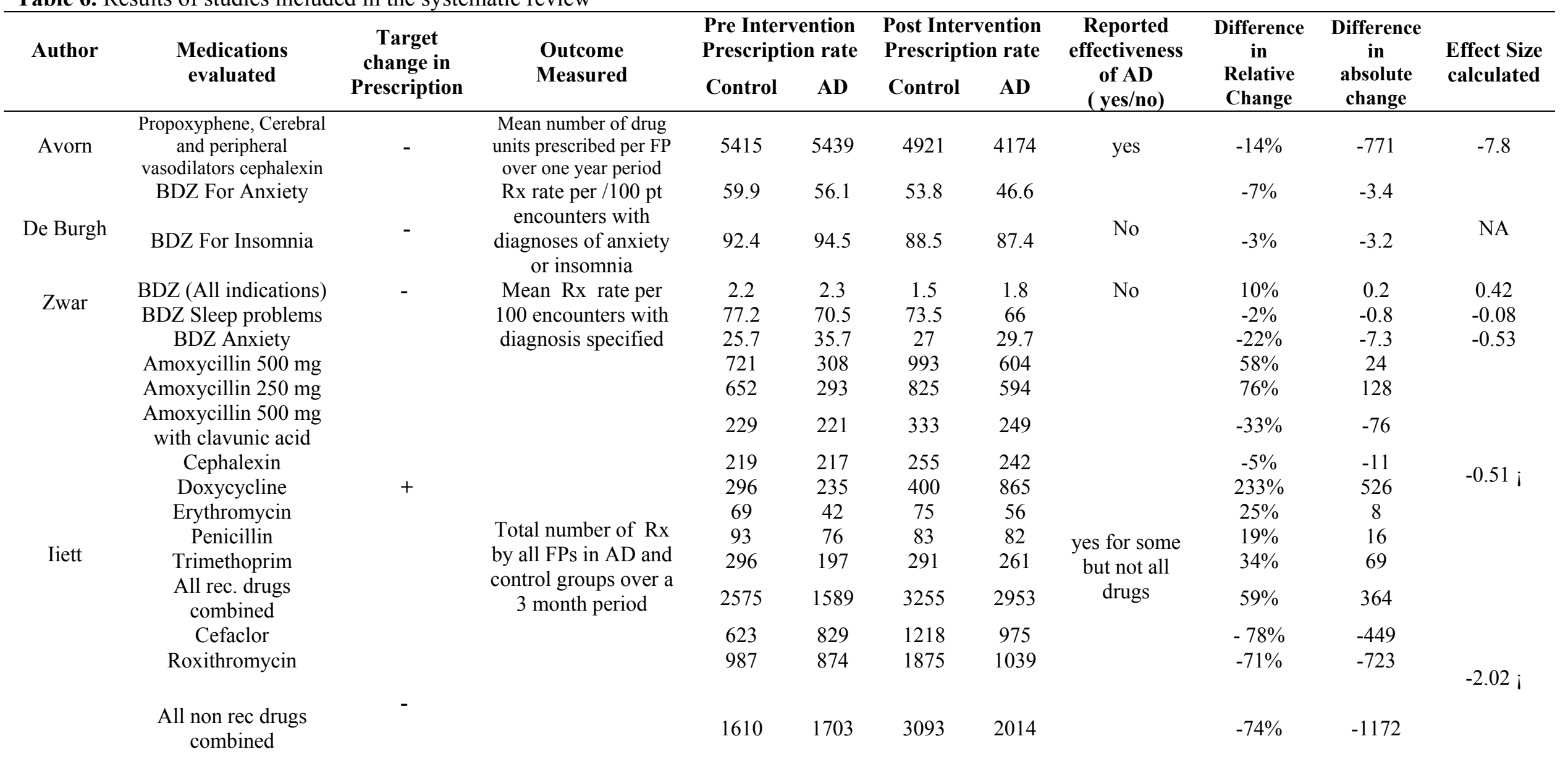


J Pharm Pharm Sci (www.cspsCanada.org) 16(4) 511 - 529, 2013

\begin{tabular}{|c|c|c|c|c|c|c|c|c|c|c|c|}
\hline \multirow{2}{*}{ Author } & \multirow{2}{*}{ Medications evaluated } & \multirow{2}{*}{$\begin{array}{c}\text { Target } \\
\text { change in } \\
\text { Prescription }\end{array}$} & \multirow{2}{*}{ Outcome } & \multicolumn{2}{|c|}{$\begin{array}{l}\text { Pre Intervention } \\
\text { Prescription rate }\end{array}$} & \multicolumn{2}{|c|}{$\begin{array}{l}\text { Post Intervention } \\
\text { Prescription rate }\end{array}$} & \multirow{2}{*}{$\begin{array}{c}\text { Reported } \\
\text { effectiveness } \\
\text { of } \mathrm{AD}, \text { yes/no) }\end{array}$} & \multirow{2}{*}{$\begin{array}{l}\text { Difference } \\
\text { in } \\
\text { Relative } \\
\text { Change }\end{array}$} & \multirow{2}{*}{$\begin{array}{l}\text { Difference } \\
\text { in } \\
\text { Absolute } \\
\text { change }\end{array}$} & \multirow{2}{*}{$\begin{array}{l}\text { Effect Size } \\
\text { calculated }\end{array}$} \\
\hline & & & & Contro & AD & Control & AD & & & & \\
\hline Ray & NSAID & - & $\begin{array}{l}\text { Mean number of days } \\
\text { of Rx NSAIDS } \\
\text { dispensed over } 1 \text { yr } \\
\text { period per NSAID } \\
\text { user }\end{array}$ & 284.9 & 287.2 & 238.39 & 219 & yes & $-7 \%$ & -21.3 & -3.76 \\
\hline Hall & Metronidazole & & quarter, per patient & 0.29 & 0.27 & 0.37 & 0.33 & No & $-5 \%$ & -0.02 & -0.5 \\
\hline \multirow[b]{2}{*}{$\begin{array}{l}\text { Individual } \\
\text { AD }\end{array}$} & $\begin{array}{l}\text { Highly anti- } \\
\text { cholinergic }\end{array}$ & - & & 5.82 & 8.02 & 8.2 & 7.5 & \multirow{2}{*}{ Yes } & $-47 \%$ & -2.9 & \multirow[b]{2}{*}{$* *$} \\
\hline & $\begin{array}{l}\text { antidepressants } \\
\text { Less anti- cholinergic } \\
\text { antidepressants }\end{array}$ & + & $\begin{array}{l}\text { Rate of incident Rx } \\
\text { of highly or less } \\
\text { anticholinergic } \\
\text { antidepressants per }\end{array}$ & 10.32 & 11.8 & 7.9 & 17 & & $68 \%$ & +7.62 & \\
\hline \multirow{2}{*}{ Group AD } & $\begin{array}{l}\text { Highly anti-cholinergic } \\
\text { antidepressants }\end{array}$ & - & 1000 person years in & 5.82 & 6.36 & 8.2 & 5.2 & \multirow{2}{*}{ Yes } & $-59 \%$ & -3.54 & \multirow{2}{*}{$* *$} \\
\hline & $\begin{array}{l}\text { Less anti- cholinergic } \\
\text { antidepressants }\end{array}$ & + & people aged $\geq 60$ yrs & 10.32 & 12.72 & 7.9 & 14.72 & & $+39 \%$ & +4.42 & \\
\hline \multirow{5}{*}{$\begin{array}{l}\text { Bernal- } \\
\text { Delgado }\end{array}$} & Diclofenac & + & & \multicolumn{2}{|c|}{$\begin{array}{l}-16.55 \% \\
(-26,-6.82)\end{array}$} & \multicolumn{2}{|c|}{$\begin{array}{l}-9.06 \% \\
(-17.18,-0.94) \beta\end{array}$} & & $+7.49 \%$ & & +1.97 \\
\hline & Piroxicam & & $\begin{array}{l}\text { Relative change in } \\
\text { number of } \mathrm{Rx} \text { of }\end{array}$ & \multicolumn{2}{|c|}{$\begin{array}{l}-28.23 \% \\
(-40.02,16.44)\end{array}$} & \multicolumn{2}{|c|}{$\begin{array}{l}-18.52 \% \\
(-29.51,-7.53)\end{array}$} & & $+9.71 \%$ & & +2.01 \\
\hline & Aceclofenac & & $\begin{array}{l}\text { each type of NSAID } \\
\text { per FP during six }\end{array}$ & \multicolumn{2}{|c|}{$\begin{array}{l}-22.85 \% \\
(-33.84,11.86)\end{array}$} & \multicolumn{2}{|c|}{$\begin{array}{l}-29.34 \% \\
(-42.22,-16.46)\end{array}$} & Yes & $-6.49 \%$ & & -1.28 \\
\hline & Meloxicam & - & $\begin{array}{l}\text { months pre and post } \\
\text { intervention }\end{array}$ & \multicolumn{2}{|c|}{$\begin{array}{l}-1.17 \% \\
(-3.99,1.65)\end{array}$} & \multicolumn{2}{|c|}{$\begin{array}{l}-25.48 \% \\
(-37.81,13.15)\end{array}$} & & $-24.31 \%$ & & -2.63 \\
\hline & Tenaxicam & & & \multicolumn{2}{|c|}{$\begin{array}{l}14.44 \% \\
(5.22,23.66)\end{array}$} & \multicolumn{2}{|c|}{$\begin{array}{l}-22.59 \% \\
(-34.42,10.76)\end{array}$} & & $-37.03 \%$ & & -8.25 \\
\hline \multirow[b]{2}{*}{ Witt } & Inhaled Steroids & + & Number of DDD & 0.23 & 0.21 & 0.235 & 0.23 & \multirow[b]{2}{*}{ No } & $+7 \%$ & +0.015 & -0.09 \\
\hline & Beta-agonist & - & $\begin{array}{l}\text { steroids or beta- } \\
\text { agonists/ } \\
\text { child/practice }\end{array}$ & 0.2 & 0.22 & 0.25 & 0.27 & & $-2 \%$ & 0 & +0.18 \\
\hline
\end{tabular}


